\title{
A GRITIQUE OF THE REPORT OF THE COMMITTEE OF INQUIRY, WARLINGHAM PARK HOSPITAL
}

\author{
By Brian Glaister, B.Sc., Ph.D., A.B.P.S., \\ Principal Psychologist, Netherne Hospital, Coulsdon
}

\section{Summary}

The Committee's terms of reference were 'To inquire into the deaths by suicide of patients at Warlingham Park Hospital during 1974 and 1975 and to prepare a Report to the Area Health Authority on these and the wider significance in relation to psychiatric care facilities in Croydon.' The 143-page Report (Committee of Inquiry, Warlingham Park Hospital 1976) is now being read by the local public who demanded the inquiry and by psychiatric hospital managers who expect to find causes and cures for suicides in their own hospitals. Unfortunately, the Report fails to reveal that the suicides were of doubtful significance; that the suggested causes are of even more doubtful validity; and that there was a period of abnormally low rate immediately prior to the period in question, the causes of which the Committee failed to investigate.

\section{The Inquiry}

During 1975, the Croydon Adoertiser carried headlines and several leading articles on the suicide of 14 inpatients at Warlingham Park Hospital which had taken place between March 1974 and July 1975 . Latterly, these articles demanded public enlightenment and were often accompanied by reports of defensive interviews with Hospital and Area managers. A local M.P. headed the campaign to force the Secretary of State to conduct an inquiry, and this was followed by the appointment of a three-person Committee of Inquiry by the Croydon Area Health Authority.

The Committee investigated: the recent history of the hospital; the conditions in the wards where the dead patients had been accommodated; the biographies of the deceased; the number of Warlingham Park patients committing suicide in each of the last 15 years; the number of patients committing suicide in each of the last 4 years for 14 other selected mental hospitals; staffing ratios at Warlingham Park compared with other areas, for in-patients, out-patients and day-patients; and relations with the press. They found that the Area's community mental health services were exceptionally extensive while its total mental nurse/mental inpatient ratio was exceptionally low. They concluded that there was an abnormally high suicide rate in the period concerned and that 18 factors (Summary, paragraph 12) caused an increase in the carrying out of suicidal intentions'. And they urged better relations with the press.

\section{The Gritique}

The Table gives the relevant data, which do not suggest a trend in suicide rate change over the whole period. Any post-hoc selection of periods to compare runs the risk of arbitrariness, but the three periods designated in the Table appear relevant in that the suicide rates within each are fairly homogeneous. Years 1972 and 1973 are intermediate in rate between the preceding and following years and could equally legitimately be included in Period $\mathbf{C}$ or classed separately, without altering the conclusions of the analysis. The comparison of Periods $A$ and $B$ shows the suicide rate in Period $B$ to be significantly lower than in the previous Period $\left(x^{2}=5.88: \mathrm{P}<0.02\right)$. The comparison of Periods $A$ and $C$ is suggestive of a higher rate in Period $\mathrm{C}\left(x^{2}=3.84: \mathrm{P}=0.05\right)$. The comparison of Periods $B$ and $\mathbf{C}$ is, of course, significant $\left(X^{2}=22 \cdot 12: \mathrm{P}<0 \cdot 001\right)$ and can most readily be interpreted as showing a lowered rate in Period $B$, in view of the previous comparisons.

A comparison of change in conditions in the hospital between Periods A and B would throw light on the causes of the drop in suicide rates in Period B, while a similar comparison of conditions in Periods $A$ and $\mathbf{C}$ would throw light on the possibly raised rate in Period C. A comparison of conditions in Periods $B$ and $C$ would throw light on the reasons for return to normal rate. Information on hospital conditions provided in the Report was not collected for the purpose of making these relevant comparisons, and attempts to make them, based on this information, are too speculative to be worthwhile.

The Report excuses its failure to describe any statistical comparisons by stating (paragraph $4.6 \mathrm{~B}$ ): 'It was accordingly necessary to refer the in-patient figures and details for statistical consideration. This we did, and we have had confirmed to us the view ... that the likelihood of the 1974-1975 average figure being a chance "hiccup" is small. We accept this view, but do not think that it is necessary for us to set out the technical reasons for it in this report.' However, the Committee of Inquiry was appointed to examine the technical matter of the significance (if any) of the suicides, and their failure to carry out 
Suicides, Admissions and Residence at Warlingham Park Hospital, rg60-75

\begin{tabular}{|c|c|c|c|c|c|c|c|}
\hline $\begin{array}{l}\text { Code for } \\
\text { period of } \\
\text { suicide } \\
\text { Homogeneity }\end{array}$ & Year & $\begin{array}{c}\text { Number } \\
\text { admitted } \\
\text { during } \\
\text { year }\end{array}$ & $\begin{array}{l}\text { Number } \\
\text { resident } \\
\text { 3I Dec. }\end{array}$ & $\begin{array}{l}\text { Number } \\
\text { committing } \\
\text { suicide } \\
\text { during } \\
\text { year }\end{array}$ & $\begin{array}{c}\text { Number } \\
\text { not } \\
\text { committing } \\
\text { suicide } \\
\text { during } \\
\text { period* }\end{array}$ & $\begin{array}{l}\text { Number } \\
\text { committing } \\
\text { suicide } \\
\text { during } \\
\text { period }\end{array}$ & $\begin{array}{c}\text { Percentage } \\
\text { committing } \\
\text { suicide } \\
\text { during } \\
\text { period }\end{array}$ \\
\hline A & $\begin{array}{l}1960 \\
1961 \\
1962 \\
1963 \\
1964 \\
1965\end{array}$ & $\begin{array}{l}900 \\
975 \\
937 \\
978 \\
982 \\
977\end{array}$ & $\begin{array}{l}970 \\
946 \\
934 \\
9^{18} \\
882 \\
848 \\
824\end{array}$ & $\begin{array}{l}2 \\
2 \\
2 \\
1 \\
2 \\
3\end{array}$ & 6,707 & 12 & $0 \cdot 18$ \\
\hline B & $\begin{array}{l}1966 \\
1967 \\
1968 \\
1969 \\
1970 \\
1971 \\
1972 \\
1973\end{array}$ & $\begin{array}{l}\mathbf{1}, 016 \\
\mathbf{1}, 058 \\
\mathbf{1}, 103 \\
\mathbf{1}, 220 \\
1,387 \\
\mathbf{1}, 303 \\
\mathbf{1}, 301 \\
\mathbf{1}, 306\end{array}$ & $\begin{array}{l}859 \\
864 \\
833 \\
798 \\
797 \\
731 \\
703 \\
665\end{array}$ & $\begin{array}{l}0 \\
0 \\
0 \\
0 \\
2 \\
0 \\
1 \\
2\end{array}$ & 10,513 & 5 & 0.05 \\
\hline C & $\begin{array}{l}1974 \\
1975\end{array}$ & $\begin{array}{l}1,444 \\
1,316\end{array}$ & $\begin{array}{l}5^{86} \\
529\end{array}$ & $\begin{array}{l}8 \\
6\end{array}$ & $3,4^{11}$ & 14 & 0.41 \\
\hline
\end{tabular}

* Calculated as number resident on 31 December of the year before the start of the period, plus the total of admissions for each year during the period, minus the number committing suicide during the period.

relevant statistical comparisons makes the Report entirely inadequate. From this failure derived the failure to realize that the suicide rate was abnormally low in Period $B$ and the failure to investigate the reasons for this-more important than the reasons for the doubtfully raised rate in Period C.

The Committee assumed that conditions which changed over the whole of Periods A, B and C could be explanatory of the possible rise in Period C, whereas in reality they could be equally explanatory of the drop in rate in Period B. They concentrated all their work on explaining the possibly abnormally high rate in Period $\mathrm{C}$, while devoting none to the much more certain abnormally low rate in Period B. The factors which they adduce as possible causes of the possible rise in Period $\mathbf{C}$ appear equally likely to have discriminated Periods $\mathrm{A}$ and $\mathrm{B}$. The Committee also compare Warlingham Park with other hospitals and conclude that various factors account for Warlingham Park's (assumed) higher rate. Their data show that these factors obtained during the period of abnormally low suicides. Would they now wish to advance them as causes of the abnormally low rate?

\section{The Lessons}

I suggest that the following lessons can be learned from this fiasco. Firstly, the bascless conclusions of an official inquiry can allay public anxiety and affect the management of the original and other hospitals. Secondly, a behavioural scientist should be included when future Committees of Inquiry into psychiatric hospitals are appointed. Thirdly, the hospital reduced its suicide figures in 1966-73, at a time when its total nurse/in-patient ratio was abnormally low and its out-patient and day-patient services unusually high, and deserves the credit for this. 